2011-6

\title{
Validated TRNSYS Model for Forced Circulation Solar Water Heating Systems with Flat Plate and Heat Pipe Evacuated Tube Collectors
}

\author{
Lacour Ayompe \\ Technological University Dublin, lacour.ayompe@tudublin.ie \\ Aidan Duffy \\ Technological University Dublin, aidan.duffy@tudublin.ie \\ Sarah McCormack \\ Trinity College
}

See next page for additional authors

Follow this and additional works at: https://arrow.tudublin.ie/engschcivart

Part of the Environmental Engineering Commons

\section{Recommended Citation}

Ayompe, L., Duffy, A., McCormack, S., Conlon, M.: Validated TRNSYS Model for Forced Circulation Solar Water Heating Systems with Flat Plate and Heat Pipe Evacuated Tube Collectors. Applied Thermal Engineering. Vol. 31, Issue 8-9, pp. 1536-1542. June, 2011. doi:10.1016/j.applthermaleng.2011.01.046

This Article is brought to you for free and open access by the School of Civil and Structural Engineering at ARROW@TU Dublin. It has been accepted for inclusion in Articles by an authorized administrator of ARROW@TU Dublin. For more information, please contact arrow.admin@tudublin.ie, aisling.coyne@tudublin.ie, gerard.connolly@tudublin.ie.

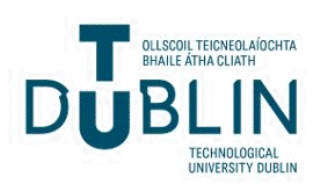




\section{Authors}

Lacour Ayompe, Aidan Duffy, Sarah McCormack, and Michael Conlon

This article is available at ARROW@TU Dublin: https://arrow.tudublin.ie/engschcivart/22 


\section{AUTHOR QUERY FORM}

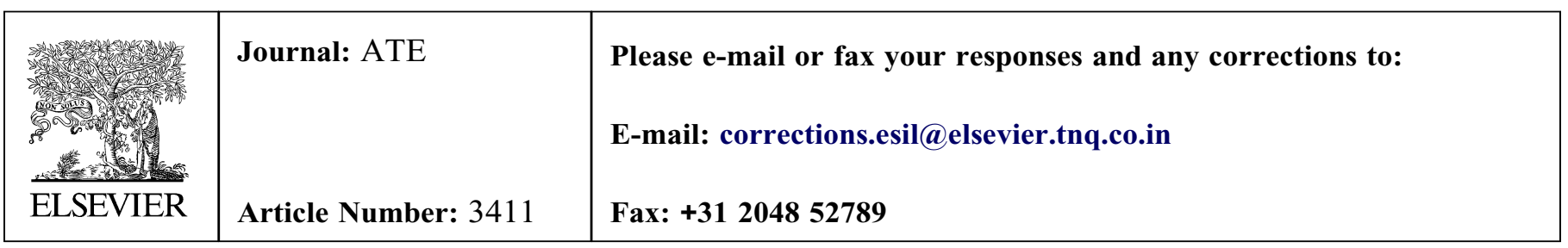

Dear Author,

Please check your proof carefully and mark all corrections at the appropriate place in the proof (e.g., by using on-screen annotation in the PDF file) or compile them in a separate list. To ensure fast publication of your paper please return your corrections within 48 hours.

For correction or revision of any artwork, please consult http://www.elsevier.com/artworkinstructions.

Any queries or remarks that have arisen during the processing of your manuscript are listed below and highlighted by flags in the proof.

\begin{tabular}{|c|l|}
\hline $\begin{array}{c}\text { Location } \\
\text { in article }\end{array}$ & \multicolumn{1}{c|}{$\begin{array}{c}\text { Query / Remark: Click on the Q link to find the query's location in text } \\
\text { Please insert your reply or correction at the corresponding line in the proof }\end{array}$} \\
\hline Q1 & $\begin{array}{l}\text { Please provide Research highlights } 3 \text { to } 5 \text { bullet points (max. 85 characters per bullet point including } \\
\text { spaces); For more information visit www.elsevier.com/researchhighlights. }\end{array}$ \\
\hline
\end{tabular}

Thank you for your assistance. 


\title{
Validated TRNSYS model for forced circulation solar water heating systems with flat plate and heat pipe evacuated tube collectors
}

\author{
L.M. Ayompe a,d,*, A. Duffy ${ }^{\mathrm{a}, \mathrm{d}}$, S.J. McCormack ${ }^{\mathrm{b}}$, M. Conlon ${ }^{\mathrm{c}, \mathrm{d}}$ \\ a Department of Civil and Structural Engineering, School of Civil and Building Services, Dublin Institute of Technology, Bolton Street, Dublin 1, Ireland \\ ${ }^{\mathrm{b}}$ Department of Civil, Structural and Environmental Engineering, Trinity College Dublin, Dublin 2, Ireland \\ ${ }^{c}$ School of Electrical Engineering Systems, Dublin Institute of Technology, Kevin St, Dublin 8, Ireland \\ ${ }^{\mathrm{d}}$ Dublin Energy Lab, FOCAS Institute, Dublin Institute of Technology, Dublin 8, Ireland
}

\section{A R T I C L E I N F O}

\section{Article history:}

Received 19 October 2010

Accepted 29 January 2011

Available online $\mathrm{xxx}$

\section{Keywords:}

Solar water heater

Flat plate collector

Evacuated tube collector

TRNSYS

\section{Introduction}

In developed countries, fuel consumption in the building sector accounts for $40 \%$ of the world's energy end use. Most of this consumption is used for heating, cooling, ventilation and sanitary hot water of which two-thirds is used in households where heating alone accounts for more than 50\% [1]. Hot water is required for taking baths and for washing clothes, utensils and other domestic purposes in urban as well as in rural areas. Water is generally heated by burning non-commercial fuels, namely, firewood as in the rural areas and commercial fuels such as kerosene oil, liquid petroleum gas (LPG), coal and electricity (either by geysers or immersion heaters) in urban areas [2]. In this regard, utilization of solar energy through solar water heating (SWH) systems plays a big role in the quantity of conventional energy required [3]. Solar water heaters therefore have significant potential to reduce environmental pollution arising from the use of fossil fuels [4].

* Corresponding author. Department of Civil and Structural Engineering, School of Civil and Building Services, Dublin Institute of Technology, Bolton Street, Dublin 1, Ireland.

E-mail address: lacour.ayompe@dit.ie (L.M. Ayompe).
Solar water heaters are the most popular means of solar energy utilization because of technological feasibility and economic attraction compared with other kinds of solar energy utilization. Solar water heater technology has been well developed and can be easily implemented at low cost [5].

Almost all solar water heating systems used in temperate climates are active systems that make use of pumps to circulate the heat transfer fluid. These systems commonly use flat plate or evacuated tube collectors, which absorb both diffuse and direct solar radiation and function even under clouded skies. Water is heated in the collectors and a pump is used to circulate a water glycol mixture used as the heat transfer fluid. A solar controller triggers the pump when the difference between the temperature of water at the bottom of the tank and the heat transfer fluid at the outlet from the collector exceeds a set value. A solar coil at the bottom of the hot water tank is used to heat water. This fluid has some desirable properties such as low freezing and high boiling points. Their ease of operation and low cost makes them suitable for low temperature applications below $80^{\circ} \mathrm{C}$. An auxiliary heating system is used to raise the water temperature during periods when there is less heat available from the solar collector.

Temperate climates are those without temperature extremes and precipitation (rain and snow) with changes between summer and winter being generally refreshing without being frustratingly 


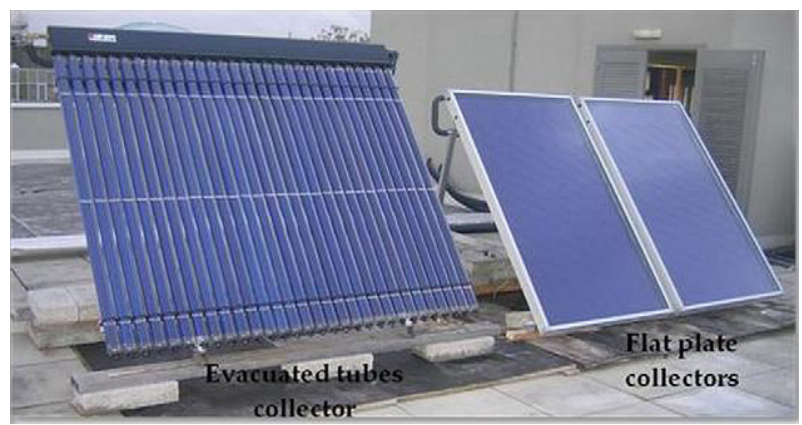

Fig. 1. Evacuated tube and flat plate collectors.

extreme. A temperate weather however, can have a very changeable weather in both summer and winter. One day it may be raining, the next it may be sunny. These climates are located in zones in the range of latitudes between 40 and $60 / 70^{\circ}$ North.

Solar water heating collectors have been studied both experimentally and theoretically by a number of researchers. Azad [6] investigated the thermal behaviour of a gravity assisted heat pipe solar collector experimentally and theoretically using the effectiveness-NTU method. Hussein [7] developed and validated a simulation model for a wickless heat pipe flat plate solar collector with a cross flow heat exchanger. Riffat et al. [8] constructed a thin membrane flat plate heat pipe solar collector and developed an analytical model that was used to simulate heat transfer processes occurring in the collector and calculate its efficiency. Bong et al. [9] presented a validated theoretical model to determine the efficiency, heat removal factor, and outlet water temperature of a single collector and an array of flat plate heat pipe collectors. Ezekwe [10] analysed the thermal behaviour of solar energy systems using heat pipe absorbers and compared them with systems using conventional solar collectors. Bojić et al. [11] modelled and simulated the performance of a forced circulation solar water heating system using a time marching model.

Most of the studies carried out on solar water heating systems have been focused on solar collectors rather than the complete systems with very few studies reported in literature. However, several researchers have carried out studies on hybrid PV-thermal systems as reported in Kalogirou [12]. He modelled and simulated the performance of a hybrid PV-thermal solar system using TRNSYS and typical meteorological year (TMY) conditions for Nicosia, Cyprus.

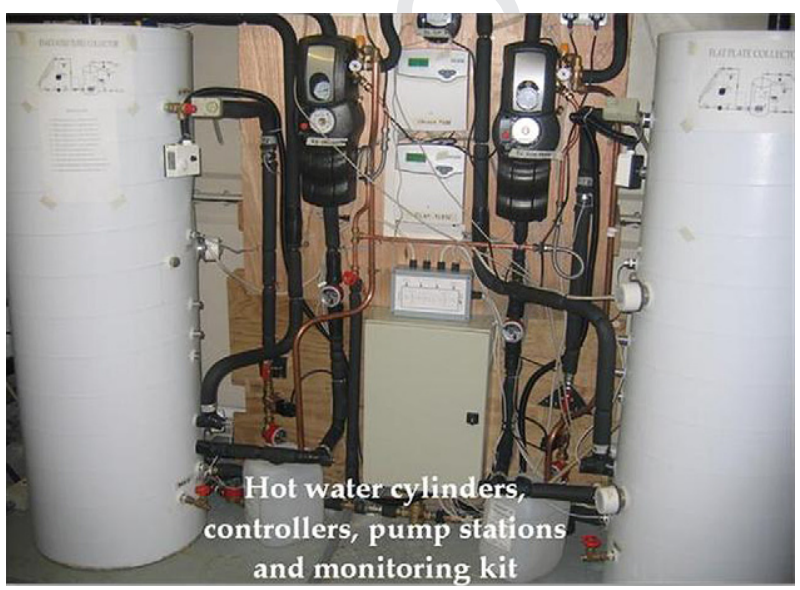

Fig. 2. In-door installation of the experimental rig.

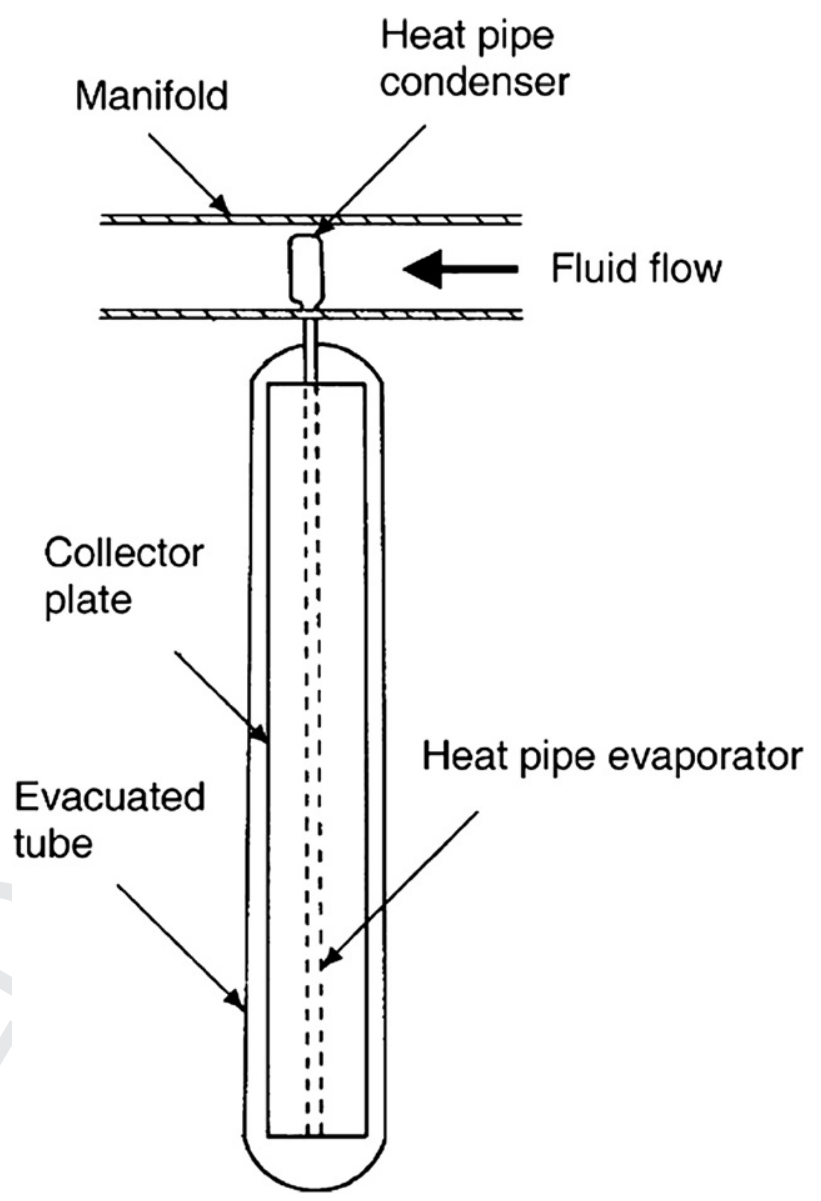

Fig. 3. Schematic diagram of a heat pipe evacuated tube collector.

The objective of this paper is to develop a TRNSYS simulation model for forced circulation solar water heating systems with flat plate and heat pipe evacuated tube collectors and validate the model using measured field performance data. The validated model will be useful for long-term performance simulation under different weather and operating conditions. The model could also be used for system optimisation under different load profiles.

\section{System description}

Typical solar water heating systems used in temperate climates consist of a hot water storage tank, control unit, pump station and either flat plate, evacuated tube or concentrating parabolic collectors. The collectors used in this study were installed on a flat roof of the Focas Institute building, Dublin Institute of Technology, Dublin, Ireland. They were south facing and inclined at $53^{\circ}$ equal to the local latitude of the location. The hot water cylinders were installed nearby in the building's plant room. The solar circuits consisted of $12 \mathrm{~mm}$ diameter copper pipes insulated with $22 \mathrm{~mm}$ thick Class $\mathrm{O}$ Armaflex. All pipe fittings were also insulated to reduce heat losses. The solar circuit pipe lengths for the heat pipe evacuated tube collector supply and return were $14 \mathrm{~m}$ and $15.4 \mathrm{~m}$ respectively, while they were $14 \mathrm{~m}$ and $15.6 \mathrm{~m}$ respectively for the flat plate collector system. Figs. 1 and 2 show pictures of the evacuated tube and flat plate collectors as well as the in-door installations of the experimental rig.

The evacuated tube collector was a Thermomax HP200 consisting of a row of 30 heat pipe evacuated tubes and an insulated 


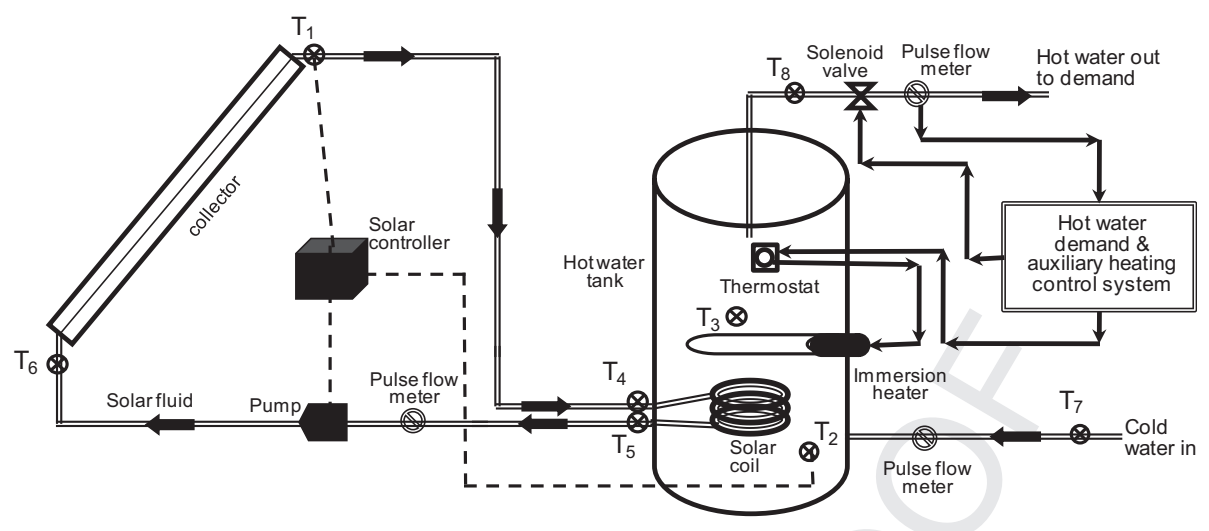

Fig. 4. Schematic diagram of the solar water heating systems.

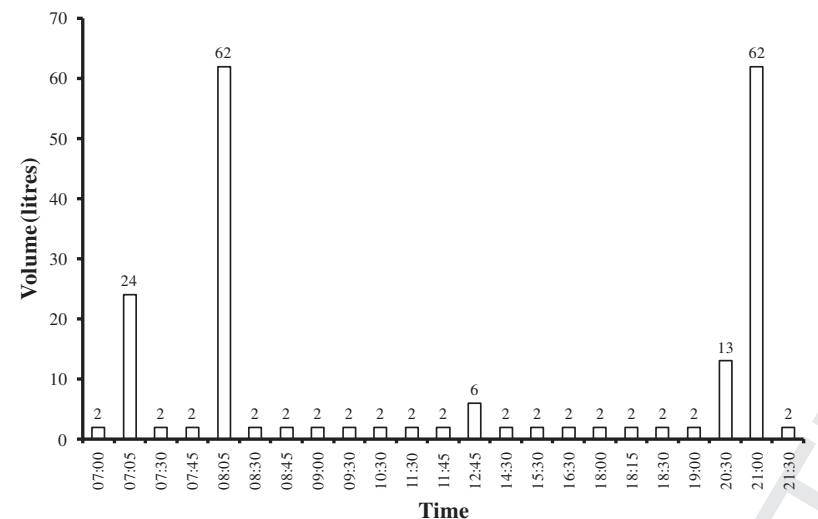

Fig. 5. Volume of hot water draw-off at different times of the day.

water manifold. The collector had an absorber surface of $3 \mathrm{~m}^{2}$ and the tubes had a vacuum level of $10^{-5}$ mbar. These solar collectors consist of a heat pipe inside a vacuum-sealed tube, as shown in Fig. 3. The vacuum envelope reduces convection and conduction losses, so the collectors can operate at higher temperatures than FPC. Like FPC, they collect both direct and diffuse radiation. However, their efficiency is higher at low incidence angles. This effect tends to give ETC an advantage over FPC in day-long performance [13]. Heat pipes are structures of very high thermal conductance. They permit the transport of heat with a temperature drop, which are several orders of magnitude smaller than for any solid conductor of the same size. Heat pipes consist of a sealed container with a small amount of working fluid. The heat is transferred as latent heat energy by evaporating the working fluid in a heating zone and condensing the vapour in a cooling zone, the circulation is completed by return flow of the condensate to the heating zone through the capillary structure which lines the inner wall of the container [14,15].

The FPC system consisted of two K420-EM2L flat plate collectors each with a gross area of $2.18 \mathrm{~m}^{2}$ and aperture area of $2 \mathrm{~m}^{2}$ connected in series giving a total area of $4 \mathrm{~m}^{2}$. Each collector had maximum operating and stagnation temperatures of $120{ }^{\circ} \mathrm{C}$ and $191{ }^{\circ} \mathrm{C}$ respectively, a maximum operating pressure of $10 \mathrm{bar}$ and fluid content of $1.73 \mathrm{~L}$.

Each system was equipped with a $300 \mathrm{~L}$ stainless steel hot water cylinder (model HM 300L D/coil U44332). The cylinder height and

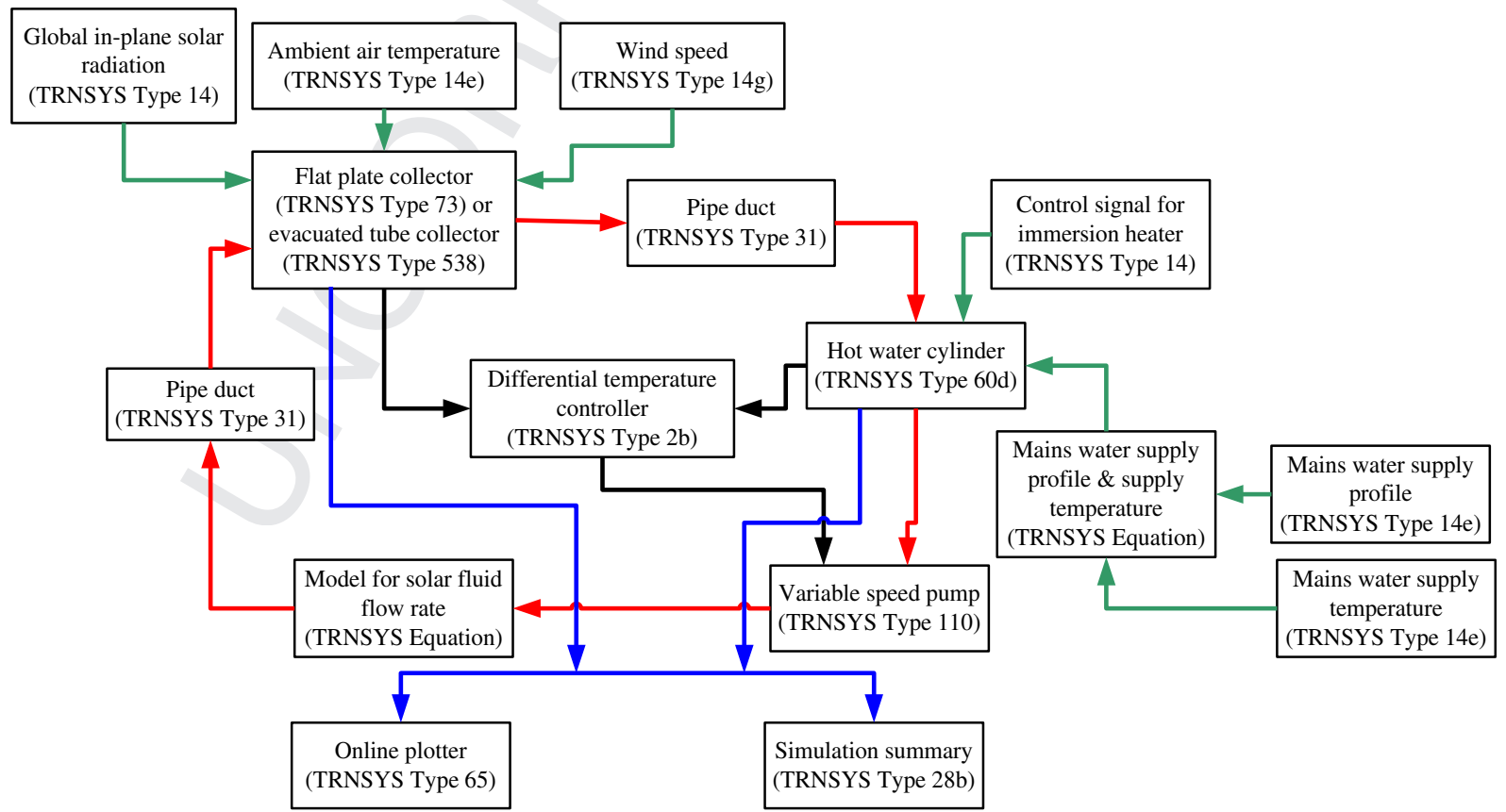

Fig. 6. TRNSYS information flow diagram for the forced circulation solar water heating systems. 
Table 1

Hot water cylinder parameters.

\begin{tabular}{|c|c|c|}
\hline Parameter & Value & Unit \\
\hline User specified inlet positions & 2 & \\
\hline Tank volume & 0.3 & $\mathrm{~m}^{3}$ \\
\hline Tank height & 1.68 & $\mathrm{~m}$ \\
\hline Height of flow inlet 1 & 0.2 & $\mathrm{~m}$ \\
\hline Height of flow outlet 1 & 1.6 & $\mathrm{~m}$ \\
\hline Fluid specific heat & 4.19 & $\mathrm{kJkg}^{-1} \mathrm{~K}^{-1}$ \\
\hline Fluid density & 1000 & $\mathrm{kgm}^{-3}$ \\
\hline Tank loss coefficient & 0.3 & $\mathrm{Wm}^{-2} \mathrm{~K}^{-1}$ \\
\hline Fluid thermal conductivity & 1.4 & $\mathrm{kJhr}^{-1} \mathrm{~m}^{-1} \mathrm{~K}^{-1}$ \\
\hline Boiling temperature & 100 & ${ }^{\circ} \mathrm{C}$ \\
\hline Height of $1^{\text {st }}$ auxiliary heater & 1 & $\mathrm{~m}$ \\
\hline Height of $1^{\text {st }}$ thermostat & 1.5 & $\mathrm{~m}$ \\
\hline Set point temperature for element 1 & 60 & ${ }^{\circ} \mathrm{C}$ \\
\hline Dead band for heating element 1 & 5 & Delta C \\
\hline Maximum heating rate of element 1 & 9900 & $\mathrm{kJhr}^{-1}$ \\
\hline Fraction of glycol & 0.4 & \\
\hline Heat exchanger inside diameter & 0.016 & $\mathrm{~m}$ \\
\hline Heat exchanger outside diameter & 0.02 & $\mathrm{~m}$ \\
\hline Heat exchanger fin diameter & 0.02 & $\mathrm{~m}$ \\
\hline Total surface area of heat exchanger & 1.4 & $\mathrm{~m}^{2}$ \\
\hline Heat exchanger length & 2.0 & $\mathrm{~m}$ \\
\hline Heat exchanger wall conductivity & 1.8 & $\mathrm{kJhr}^{-1} \mathrm{~m}^{-1} \mathrm{~K}^{-1}$ \\
\hline Heat exchanger material conductivity & 1.8 & $\mathrm{kJhr}^{-1} \mathrm{~m} \mathrm{~K}^{-1}$ \\
\hline Height of heat exchanger inlet & 0.4 & $\mathrm{~m}$ \\
\hline Height of heat exchanger outlet & 0.3 & $\mathrm{~m}$ \\
\hline
\end{tabular}

diameter were $1680 \mathrm{~mm}$ and $580 \mathrm{~mm}$ respectively, with an operating pressure of 3 bar. Each cylinder was fitted with two immersion heaters of $2.75 / 3.0 \mathrm{~kW}$ capacity located at the bottom and middle of the tank. The cylinders each had two heating coils with surface areas of $1.4 \mathrm{~m}^{2}$ and $21 \mathrm{~kW}$ rating. The bottom coil was used by the solar heating circuit while the top coil was reserved for use with auxiliary heating systems such as boilers.

A programmable logic controller (PLC) turned on the immersion heaters between 5 and 8 am and 6-9 pm daily just before the two peak hot water draw-offs. Analogue thermostats placed at the top of the hot water cylinders were set to turn-off the electricity supply to the immersion heaters when the temperature of water at the top of the tank exceeded $60^{\circ} \mathrm{C}$. Fig. 4 shows a schematic diagram of the solar water heating systems.

Hot water was dispensed using solenoid valves that were opened and closed using signals from the PLC. Pulse flow metres (1 pulse per litre) installed at the end of the solenoid valves were used to count the number of litres of water extracted from the hot water cylinders. The solenoid valves were closed when the required volume of water was dispensed. The hot water demand profile employed was the EU reference tapping cycle number 3, featuring 24 draw-offs with the energy output of $11.7 \mathrm{kWh}$ equivalent to

Table 3

Pump parameters.

\begin{tabular}{lll}
\hline Parameter & Value & Unit \\
\hline Rated flow rate (FPC) & 212 & $\mathrm{kghr}^{-1}$ \\
Rated flow rate (ETC) & 330 & $\mathrm{kghr}^{-1}$ \\
Fluid specific heat capacity & 3.708 & $\mathrm{kJkg}^{-1} \mathrm{~K}^{-1}$ \\
Rated power & 226.8 & $\mathrm{kJhr}^{-1}$ \\
\hline
\end{tabular}

a total volume of $200 \mathrm{~L}$ at $60{ }^{\circ} \mathrm{C}$ daily. It is based on the European Union mandate for the elaboration and adoption of measurement standards for household appliances EU M324EN [16]. Fig. 5 shows the recommended volume of hot water to be extracted at different times of the day.

\section{Modelling}

\subsection{TRNSYS model}

The solar water heating system model was developed using transient systems simulation (TRNSYS) software, which is a quasisteady state simulation program. TRNSYS enables system components represented as proformas to be selected and interconnected in any desired manner to construct a system's model. In order to facilitate the selection of the system components, it is important to develop an information flow diagram. The information flow diagram for the models is shown in Fig. 6.

The main component of the model is the solar energy collector which is either a flat plate collector (Type 73) or evacuated tube collector (Type 538). Additional components to the model include: Type 31 pipe duct, Type 60d hot water cylinder with 1 inlet and 1 outlet, Type 2b differential temperature controller, Type 110 variable speed pump, Type 14 forcing functions, Type 65 online plotter and Type 28b simulation summary. Type 14 forcing functions were used several times in the model to input ambient air temperature and mains water supply temperature (Type 14e), wind speed (Type 14g), hot water demand profile (Type 14b), immersion heater control signals and in-plane solar radiation (Type 14h). Tables 1, 2 and 3 show values of parameters for the hot water cylinder, solar collectors and pump respectively used in the TRNSYS model.

\subsection{Weather data}

Weather for three days notably clear sky in summer (02/06/ 2009), intermittent cloud cover in autumn (25/11/2009) and heavily overcast in winter (20/01/2010) were chosen to represent different weather conditions prevalent in Ireland. These data were

Table 2

Solar collector parameters.

\begin{tabular}{llcc}
\hline Parameter & Unit & FPC (Value) & ETC (Value) \\
\hline Number in series & & 2 & 1 \\
Collector absorber area & $\mathrm{m}^{2}$ & 3.95 & 3.021 \\
Fluid specific heat & $\mathrm{kJkg}^{-1} \mathrm{~K}$ & 3.708 & 3.708 \\
Tested flow rate & $\mathrm{kghr}^{-1} \mathrm{~m}^{-2}$ & & 80 \\
Intercept efficiency & & 0.776 & 0.778 \\
First order efficiency coefficient & $\mathrm{kJhr}^{-1} \mathrm{~m}^{-2} \mathrm{~K}^{-1}$ & 14.22 & 3.276 \\
Second order efficiency coefficient & $\mathrm{kJhr}^{-1} \mathrm{~m}^{-2} \mathrm{~K}^{-2}$ & 0.0594 & 0.036 \\
Maximum flow rate & $\mathrm{Kghr}^{-1}$ & 212 & 330 \\
Collector slope & Degrees & 53 & 53 \\
Absorber plate emittance & & 0.7 & \\
Absorbance of absorber plate & & 0.8 & \\
Number of covers & & 1 & \\
Index of refraction of cover & & 1.526 \\
Extinction coefficient thickness product & 0.28 & \\
\hline
\end{tabular}

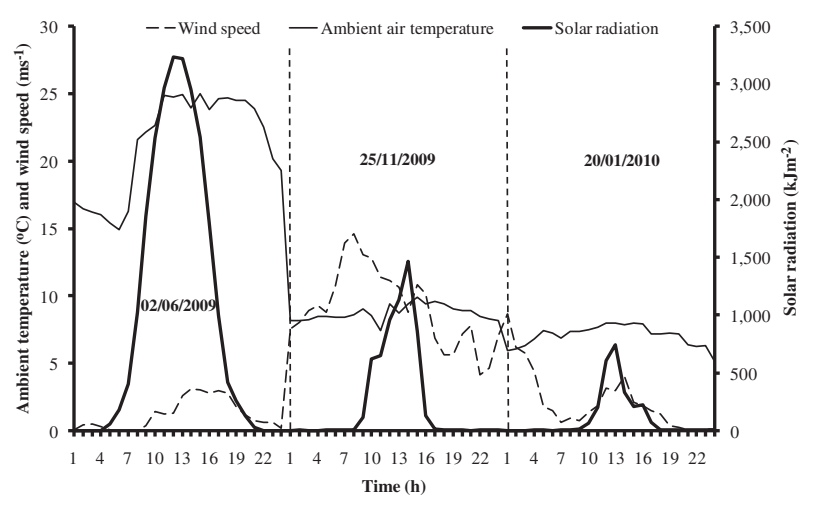

Fig. 7. Solar radiation, wind speed and ambient air temperature. 


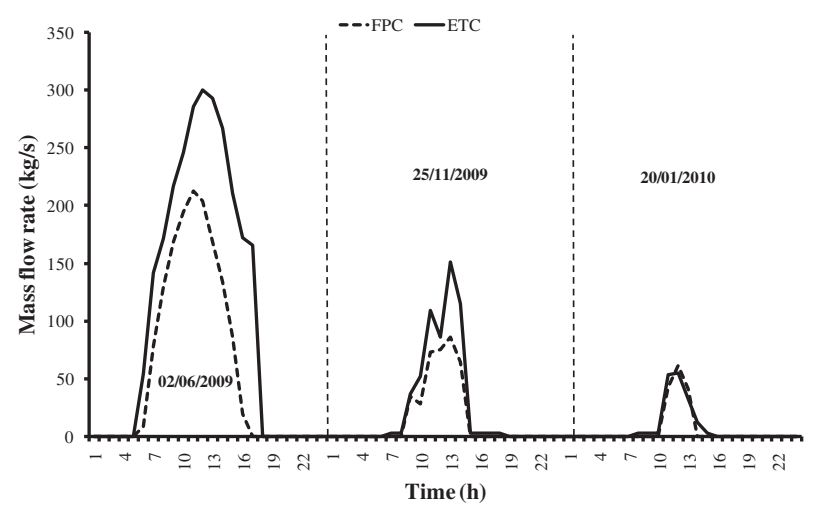

Fig. 8. Solar fluid mass flow rate for the FPC and ETC systems.

used as inputs of the TRNSYS model. Fig. 7 shows plots of mean hourly values of solar radiation, ambient air temperature and wind speed. The maximum hourly values of in-plane solar radiation were $3234 \mathrm{kJm}^{-2}, 1463 \mathrm{kJm}^{-2}$ and $745 \mathrm{kJm}^{-2}$ during the three days. The maximum hourly ambient air temperatures were $25.0{ }^{\circ} \mathrm{C}, 9.9{ }^{\circ} \mathrm{C}$ and $8.0{ }^{\circ} \mathrm{C}$ while the maximum wind speeds were $3.1 \mathrm{~ms}^{-1}$, $14.6 \mathrm{~ms}^{-1}$ and $8.7 \mathrm{~ms}^{-1}$ respectively.

\subsection{Mass flow rate}

Fig. 5 shows plots of the measured solar fluid mass flow rate for the FPC and ETC systems. It is seen that the solar fluid mass flow rate was $212.4 \mathrm{kghr}^{-1}, 85.8 \mathrm{kghr}^{-1}$ and $61.5 \mathrm{kghr}^{-1}$ for the FPC system and $300.2 \mathrm{kghr}^{-1}, 151.5 \mathrm{kghr}^{-1}$ and $54.9 \mathrm{kghr}^{-1}$ for the ETC system during the clear sky, intermittent cloud covered and heavily overcast days respectively. For both systems the solar fluid mass flow rate shows clear dependence on the level of solar radiation.

The variable speed pump (TRNSYS Type 110) operates on an on/ off sequence running at the maximum rate flow rates of $212 \mathrm{kghr}^{-1}$ and $330 \mathrm{kghr}^{-1}$ for the FPC and ETC systems respectively when on. This does not take into account the variable nature of the solar fluid mass flow rates shown in Fig. 8. The solar fluid mass flow rate was therefore modelled to reflect real-time operation of the actual pump. The fluid mass flow rate was seen to vary linearly with in-plane solar radiation and was modelled following the expression shown in Eq. (1).

$\dot{m}_{\mathrm{f}}=\mathrm{aG}_{\mathrm{t}}+\mathrm{b}$

where, $a$ and $b$ are empirical coefficients with values of 0.0623 and -2.1394 for the FPC system and 0.0976 and 2.059 for the ETC system determined using measured data. The correlation coefficients $\left(\mathrm{R}^{2}\right)$ for the FPC and ETC systems were 0.97 and 0.93 respectively. The solar fluid mass flow rate model in Eq. (1) was incorporated into the TRNSYS model using the equation proforma.

\subsection{Heat collected}

The useful energy collected by the solar energy collector is given as [17]:

Table 4

PMEA and PME for collector outlet temperature $\left(\mathrm{T}_{\mathrm{co}}\right)$, heat collected by the collector $\left(\mathrm{Q}_{\text {coll }}\right)$ and heat delivered to the load $\left(\mathrm{Q}_{\text {load }}\right)$.

\begin{tabular}{|c|c|c|c|c|c|c|}
\hline & \multicolumn{3}{|c|}{ PMAE } & \multicolumn{3}{|l|}{ PME } \\
\hline & $\mathrm{T}_{\text {co }}$ & $\mathrm{Q}_{\text {coll }}$ & Qload & $\mathrm{T}_{\text {co }}$ & $\mathrm{Q}_{\text {coll }}$ & Qload \\
\hline FPC & 16.9 & 14.1 & 6.9 & -9.7 & 7.6 & 6.9 \\
\hline ETC & 18.4 & 16.8 & 7.6 & 13.7 & 12.4 & 7.6 \\
\hline
\end{tabular}

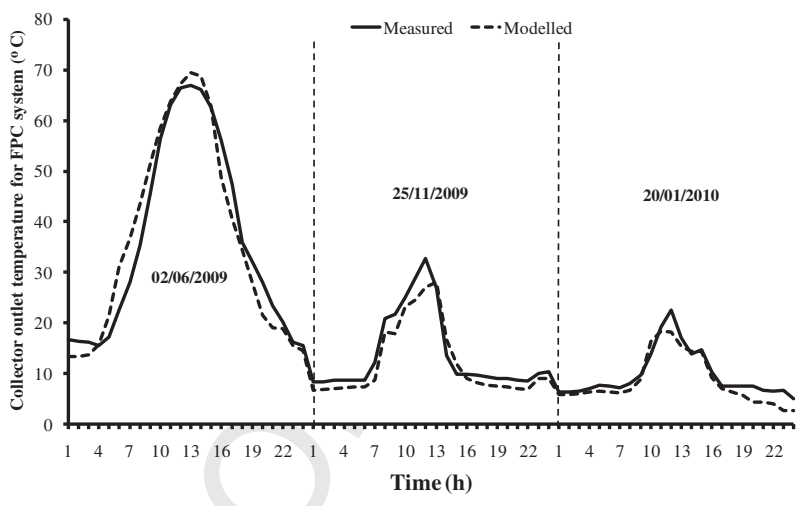

Fig. 9. Measured and modelled collector outlet temperature for FPC system.

$\mathrm{Q}_{\text {coll }}=\dot{m}_{\mathrm{f}} \mathrm{C}_{\mathrm{pf}}\left(\mathrm{T}_{1}-\mathrm{T}_{6}\right)$

\subsection{Heat delivered}

The heat delivered by the solar water heating system to the load was calculated as

$\mathrm{Q}_{\text {load }}=\dot{m}_{\mathrm{w}} \mathrm{C}_{\mathrm{pw}} \mathrm{T}_{8, \mathrm{avg}}$

\subsection{Hot water demand}

Since the hot water tanks used in this study are pressurised, the hot water demand profile shown in Fig. 5 was modelled using two TRNSYS Type 14e forcing functions each representing the mains water supply profile and temperature respectively. The outputs from the forcing functions were then combined using a TRNSYS equation proforma that had as output the mains water supply profile and temperature.

\subsection{Model validation}

In order to quantify variations between predicted and measured values, percentage mean absolute error (PMAE) and percentage mean error (PME) were used. PMAE evaluates the percentage mean of the sum of absolute deviations arising due to both over-estimation and under-estimation of individual observations. The PME evaluates the percentage mean of the sum of errors of individual observations. A negative value of PME indicates a net underestimation while a positive value indicates a net overestimation of the modelled values. PMAE and PME are given in Eqs. 4 and 5 as:

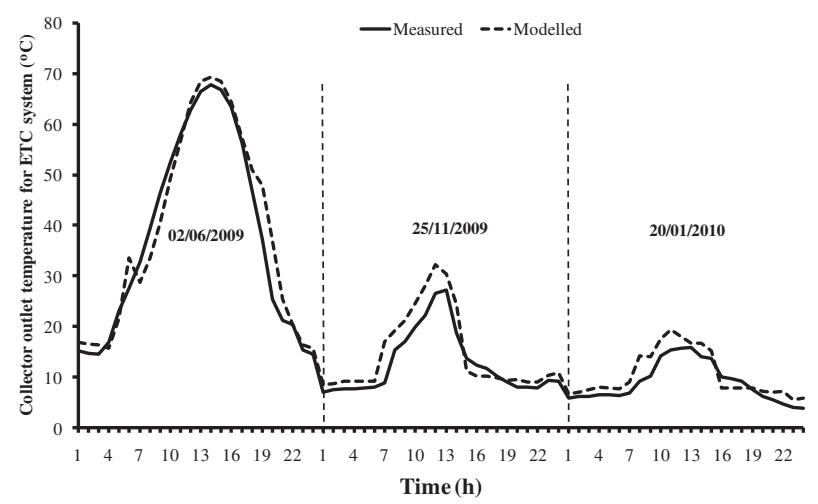

Fig. 10. Measured and modelled collector outlet temperature for ETC system. 


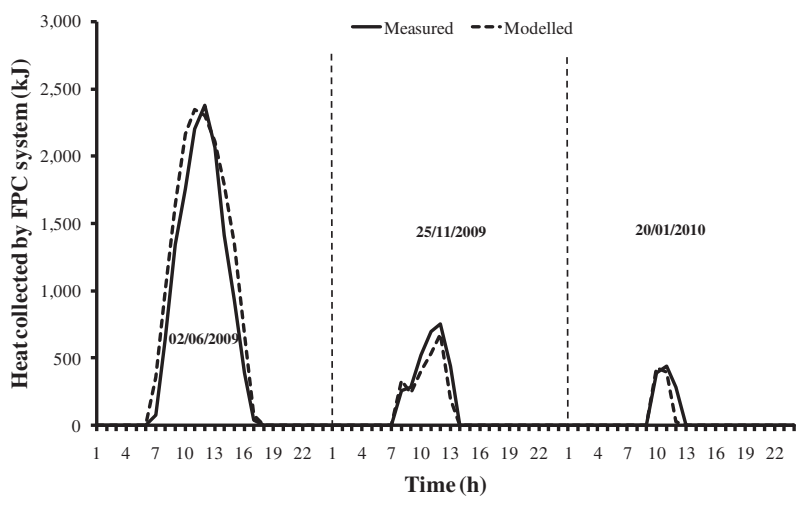

Fig. 11. Measured and predicted heat collected by the FPC system.

$\operatorname{PMAE}=\frac{100}{\mathrm{~N}} \sum_{\mathrm{i}=1}^{\mathrm{N}} \frac{\left|\mathrm{C}_{\mathrm{i}}-\mathrm{M}_{\mathrm{i}}\right|}{\mathrm{M}_{\mathrm{i}}}$

and

$P M E=\frac{100}{N} \sum_{i=1}^{N} \frac{C_{i}-M_{i}}{M_{i}}$

$\mathrm{N}$ is the total number of observations while $C_{i}$ and $M_{i}$ are the $i^{\text {th }}$ calculated and measured values, respectively.

\section{Results and discussions}

Table 4 presents percentage mean absolute errors (PMAE) and percentage mean error (PME) for collector outlet temperature $\left(\mathrm{T}_{\mathrm{co}}\right)$, heat collected by the collector $\left(\mathrm{Q}_{\mathrm{coll}}\right)$ and heat delivered to the load ( $\left.Q_{\text {load }}\right)$ for both the FPC and ETC systems. The results show that the model performed slightly better in all six cases for the FPC system. It however, predicted $\mathrm{Q}_{\text {load }}$ for the FPC system with the least PMAE of $6.9 \%$ while it predicted $\mathrm{T}_{\text {co }}$ for the ETC system with the highest PMAE of $18.4 \%$. The negative value of PME for the FPC indicates an underestimation of $\mathrm{T}_{\mathrm{co}}$ by the model.

Much of the discrepancies between the simulated and experimental results can be attributed to experimental errors which are a function of the accuracy of the measurement devices used. Also, the existing TRNSYS proformas for evacuated tube collectors might not be fully representative of heat pipes. Detailed plots of the results are presented in Sections 4.1-4.3.

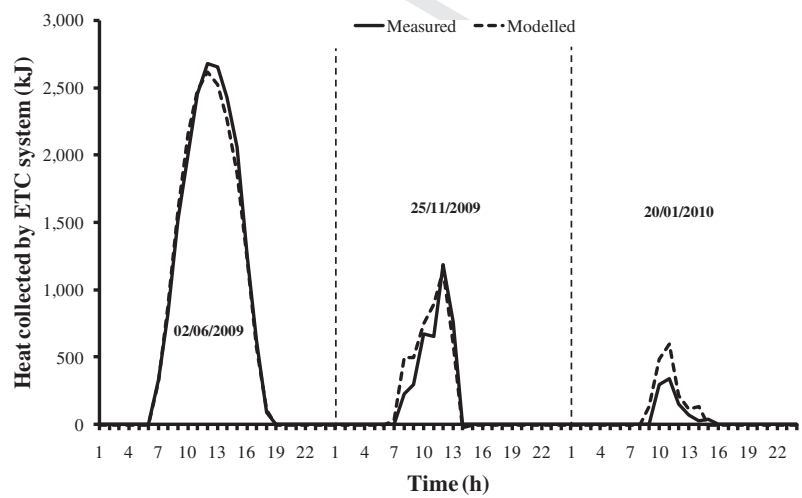

Fig. 12. Measured and modelled heat collected by the ETC system.

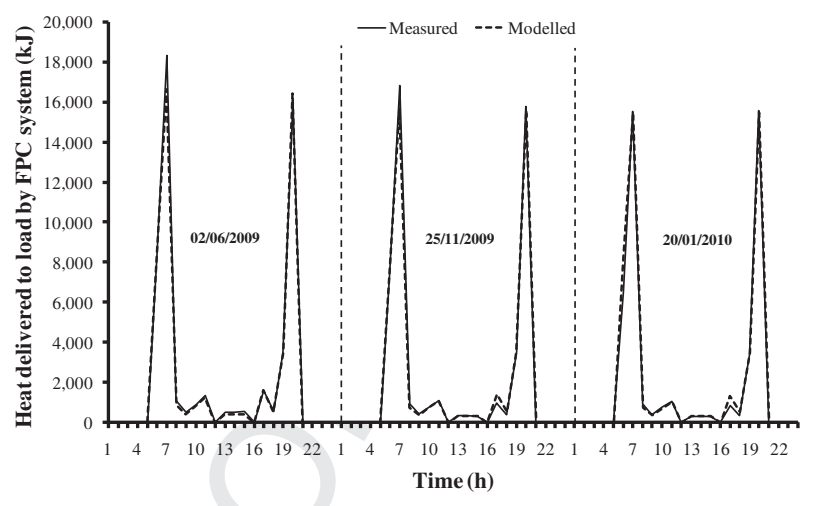

Fig. 13. Measured and modelled heat delivered to load by FPC system.

\subsection{Collector outlet temperature}

Fig. 9 shows plots of measured and modelled collector outlet temperature $\left(\mathrm{T}_{\mathrm{co}}\right)$ for the FPC system. It is seen that the modelled values follow the same trend as the measured values. The model however overestimated $\mathrm{T}_{\text {co }}$ during the bright sunny day (02/06/ 2009) while it underestimated same during the other two days. Fig. 10 shows plots of measured and modelled values of $\mathrm{T}_{\mathrm{co}}$ for the ETC system. Again it is seen that the modelled values follow the same trend as the measured values. The model however, overestimated $\mathrm{T}_{\mathrm{co}}$ during all three days.

\subsection{Heat collected}

Fig. 11 shows plots of measured and modelled heat collected $\left(\mathrm{Q}_{\text {coll }}\right)$ by the FPC. It is seen that the modelled values follow the same pattern as the measured values. The model slightly overestimated $\mathrm{Q}_{\text {coll }}$ on the bright sunny day (02/06/2009) and underestimated $\mathrm{Q}_{\text {coll }}$ during the other two days. Fig. 12 shows plots of measured and modelled heat collected $\left(\mathrm{Q}_{\text {coll }}\right)$ by the ETC. It is seen that the modelled values follow the same pattern as the measured values. The model slightly underestimated $\mathrm{Q}_{\text {coll }}$ on the bright sunny day (02/ 06/2009) and overestimated $Q_{\text {coll }}$ during the other two days.

The high discrepancy between the modelled and measured $\mathrm{Q}_{\text {coll }}$ for the ETC system was as a result of the nature of operation of the heat pipe evacuated collector which has two different circuits. The evaporation and condensation cycle of the primary heat transfer fluid in the primary circuit as well as heat removal through the secondary circuit causes the pump to intermittently switch on and off in quick succession. This sometimes results in energy loss from the hot water tank thereby reducing the net energy collected.

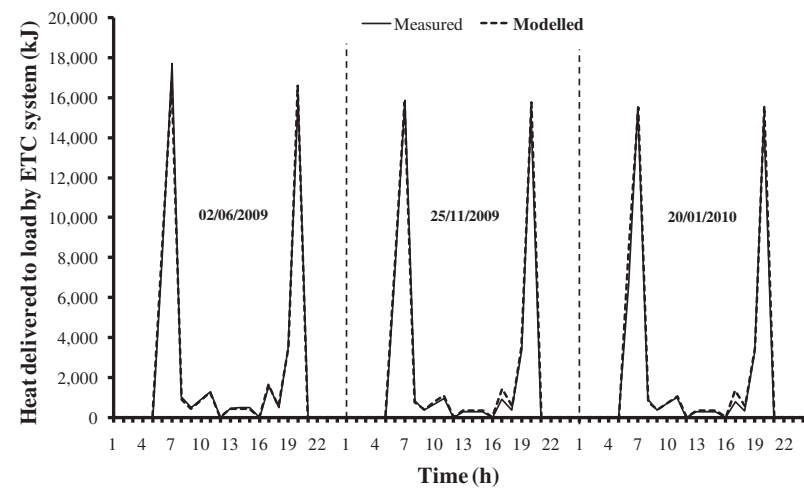

Fig. 14. Measured and modelled heat delivered to load by ETC system. 


\subsection{Heat delivered to load}

Figs. 13 and 14 show plots of measured and modelled heat delivered to the load for the FPC and ETC systems. It is seen that the model predictions for both the FPC and ETC systems closely followed the same trend as the measured heat delivered to the load during the three days with the model slightly overestimating the quantity of heat delivered to the load.

\section{Conclusions}

A TRNSYS model was developed for forced circulation solar water heating systems with flat plate and heat pipe evacuated tube collectors. The model was validated using field trial data for systems installed in Dublin, Ireland. Results obtained showed that the model predicted the collector outlet fluid temperature with percentage mean absolute error (PMAE) of $16.9 \%$ and $18.4 \%$ for the FPC and ETC systems respectively. Heat collected and delivered to the load was also predicted with PMAE of $14.1 \%$ and $6.9 \%$ for the FPC system and $16.9 \%$ and $7.6 \%$ for the ETC system respectively. The model underestimated the collector outlet fluid temperature by $-9.6 \%$ and overestimated the heat collected and heat delivered to load by $7.6 \%$ and $6.9 \%$ for the FPC system. The model overestimated all three parameters by $13.7 \%, 12.4 \%$ and $7.6 \%$ for the ETC system.

The validated TRNSYS model can be used to:

- Predict long-term performance of the solar water heating systems in different locations

- Simulate system performances under different weather and operating conditions

- Optimise solar water heating system sizes to match different load profiles.

\section{Nomenclature}

$\mathrm{C}_{\mathrm{pf}} \quad$ specific heat capacity of solar fluid $\left(\mathrm{kJkg}^{-1} \mathrm{~K}^{-1}\right)$

$\mathrm{C}_{\mathrm{pw}} \quad$ specific heat capacity of water $\left(\mathrm{kJkg}^{-1} \mathrm{~K}^{-1}\right)$

ETC evacuated tube collector

FPC flat plate collector

$\mathrm{G}_{\mathrm{t}} \quad$ in-plane solar radiation $\left(\mathrm{kJm}^{-2}\right)$

$\dot{m}_{\mathrm{f}} \quad$ solar fluid mass flow rate $\left(\mathrm{kghr}^{-1}\right)$

$\dot{m}_{\mathrm{w}} \quad$ water mass flow rate $\left(\mathrm{kghr}^{-1}\right)$
PMAE percentage mean absolute error (\%)

PME percentage mean error (\%)

$\mathrm{Q}_{\text {coll }} \quad$ heat collected by solar collector $(\mathrm{kJ})$

Q load heat delivered to load (kJ)

$\mathrm{T}_{1} \quad$ solar fluid temperature at collector outlet (K)

$\mathrm{T}_{6} \quad$ solar fluid temperature at collector inlet (K)

$\mathrm{T}_{8, \text { avg }}$ average hot water temperature delivered to load (K)

TRNSYS transient systems simulation

SWH solar water heating

\section{References}

[1] International Energy Agency, Energy Use in the New Millennium: Trends in IEA Countries (2007).<http://www.iea.org/textbase/nppdf/free/2007/millennium. pdf $>$.

[2] D.W. Lee, A. Sharma, Thermal performances of the active and passive water heating systems based on annual operation, Solar Energy 81 (2) (2007) 207-215.

[3] H. Gunerhan, A. Hepbasli, Exergetic modeling and performance evaluation of solar water heating systems for building applications, Energy and Buildings 39 (5) (2007) 509-516.

[4] S.A. Kalogirou, Environmental benefits of domestic solar energy systems, Energy Conversion and Management 45 (18-19) (2004) 3075-3092.

[5] W. Xiaowu, H. Ben, Exergy analysis of domestic-scale solar water heaters, Renewable and Sustainable Energy Reviews 9 (6) (2005) 638-645.

[6] E. Azad, Theoretical and experimental investigation of heat pipe solar collector, Experimental Thermal and Fluid Science 32 (8) (2008) 1666-1672.

[7] H.M.S. Hussein, Theoretical and experimental investigation of wickless heat pipes flat plate solar collector with cross flow heat exchanger, Energy Conversion and Management 48 (4) (2007) 1266-1272.

[8] S.B. Riffat, X. Zhao, P.S. Doherty, Developing a theoretical model to investigate thermal performance of a thin membrane heat-pipe solar collector, Applied Thermal Engineering 25 (5-6) (2005) 899-915.

[9] T.Y. Bong, K.C. Ng, H. Bao, Thermal performance of a flat-plate heat-pipe collector array, Solar Energy 50 (6) (1993) 491-498.

[10] C.I. Ezekwe, Thermal performance of heat pipe solar energy systems, Solar \& Wind Technology 7 (4) (1990) 349-354.

[11] M. Bojić, S. Kalogirou, K. Petronijevi, Simulation of a solar domestic water heating system using a time marching model, Renewable Energy 27 (3) (2002) 441-452.

[12] S.A. Kalogirou, Use of TRNSYS for modelling and simulation of a hybrid PVthermal solar system for Cyprus, Renewable Energy 23 (2) (2001) 247-260.

[13] S.A. Kalogirou, Solar thermal collectors and applications, Progress in Energy and Combustion Science 30 (3) (2004) 231-295.

[14] P.D. Dunn, D.A. Reay, Heat Pipe, third ed. Pergamon Press, New York, 1982.

[15] A. Faghri, Heat Pipe Science. Taylor \& Francis, London, 1995.

[16] European Commission, Mandate to CEN and CENELEC for the Elaboration and Adoption of Measurement Standards for Household Appliances: Water Heaters, Hot Water Storage Appliances and Water Heating Systems (2002) Brussels.

[17] S.A. Kalogirou, Solar Energy Engineering: Processes and Systems. Elsevier, London, 2009. 